\title{
The individual effect of different production systems, age and sex on the chemical composition of wild boar meat
}

\author{
Simona Tesarova ${ }^{1,2,3}$, Frantisek Jezek ${ }^{1}$, Radka Hulankova ${ }^{1,2}$, Radim Plhal ${ }^{4}$, Jakub Drimaj ${ }^{4}$, \\ Iva Steinhauserova ${ }^{1,2}$, Gabriela Borilova ${ }^{1,2}$ \\ ${ }^{1}$ University of Veterinary and Pharmaceutical Sciences Brno, Faculty of Veterinary Hygiene and Ecology, \\ Department of Meat Hygiene and Technology, Brno, Czech Republic \\ ${ }^{2}$ University of Veterinary and Pharmaceutical Sciences Brno, \\ CEITEC - Central European Institute of Technology, Brno, Czech Republic \\ ${ }^{3}$ Regional Veterinary Administration of the State Veterinary Administration for the South Moravian Region, \\ Brno, Czech Republic \\ ${ }^{4}$ Mendel University in Brno, Faculty of Forestry and Wood Technology, \\ Department of Forest Protection and Wildlife Management, Brno, Czech Republic
}

Received May 11, 2018

Accepted December 7, 2018

\begin{abstract}
Meat from wild boar (musculus teres major, $\mathrm{n}=160$ ) originating from two localities with different production systems was analysed. The contents of crude protein, pure protein, fat, collagen, dry matter and ash were determined in each sample. The effect of locality, age and sex on the chemical properties of the wild boar meat was studied with the use of statistical analysis. The values obtained for the chemical composition of the muscle tissue of the wild boar from localities $\mathrm{A}$ and $\mathrm{B}$ corresponded to the results obtained in other countries. The protein content fell within the range of $20.49-21.26 \%$ at locality A and $18.77-20.34 \%$ at locality B. The fat content fell within the wide range of $0.83-2.38 \%(0.83-1.67 \%$ at locality $\mathrm{A}$ and $1.51-2.38 \%$ at locality $\mathrm{B})$. It is clear from the statistical evaluation that wild boar hunted in the enclosed locality had a significantly higher $(P<0.05)$ fat content and a lower content of crude $(P<0.05)$ and pure $(P<0.05)$ protein in comparison with wild boar from the unenclosed locality. A significant difference in the fat content was also demonstrated between localities in animals aged $0-12$ months $(P<0.05)$, though only in females $(P<0.05)$ when younger animals $(0-12$ months $)$ were divided by sex, and also in females aged 12-24 months $(P<0.05)$. The results confirm that the composition of wild boar meat in the Czech Republic is very variable and influenced by multiple factors.
\end{abstract}

Sus scrofa, shoulder, crude protein, pure protein, fat

Game meat differs from the meat of livestock animals in colour which is darker, redder and verging on brown, and taste which is more specific and changes depending on the type of game (Skobrák et al. 2011). The composition of wild game meat shows a higher content of protein and lower content of saturated fatty acids (Strazdina et al. 2011), and is also a source of mineral elements that are important for the correct functioning of intravital processes, particularly iron, phosphorus, zinc and selenium (Skobrák et al. 2011). These findings have been confirmed by many studies on wild animals.

The most frequent properties that determine meat quality are the content of protein and connective tissue, because the protein content is the most important information about nutritional composition for ordinary consumers and the volume of connective tissue has an influence on the final tenderness of the meat (Strazdina et al. 2011).

The term game indicates the edible parts of the carcasses of hunted animals, i.e. the muscle tissue and organs (Act no. 166/1999 Coll., as amended). In the Czech Republic, game meat may come from 36 animal species specified by the hunting law (Act no. 449/2001 Coll., as amended) as wild-living game that can be "managed by hunting". The 
figures from the Czech Statistical Office show that the most frequently hunted animals are wild boar (Sus scrofa) and the common pheasant (Phasianus colchicus).

The number of wild boar shot in 2007 amounted to 100,000, and this figure has not fallen below 150,000 since 2012. Of the fourteen regions of the Czech Republic the largest number of wild boar were shot in 2016 in the Central Bohemian Region which included the capital city of Prague, followed by the Plzeň Region and the South Bohemian Region (Czech Statistical Office).

Several factors including the absence of natural predators, rural depopulation, expansion of forest areas, and spread of game managed areas have led to an increased population density of wild boar. The high natural population and farming of wild boar have revived interest in the meat producing potential of this species (Sales and Kotrba 2013).

The evaluated data on meat consumption give a mean value of consumed game of $1.0 \mathrm{~kg} / \mathrm{person} /$ year out of the total consumption of $80.3 \mathrm{~kg} /$ person/year. This figure may seem low in comparison with the total meat consumption, though the consumption of game has more than tripled over the last fifteen years (Czech Statistical Office). It is clear from these figures that game is becoming more readily available on the market for ordinary consumers.

Two factors have had a major effect on increasing the number of hunted wild boar and thereby the increased availability of wild boar meat in recent years. The first of these events was the amendment of Decree no. 245/2002 Coll. which allowed the year-round hunting of wild boar in hunting grounds that conform to the given legislative requirements. The second of these major events came about in the middle of 2017 when the African swine fever occurred in the Czech Republic for the first time. The occurrence of this highly infectious disease resulted in extraordinary veterinary measures that aimed to reduce the wild boar population in the whole country regardless of the animals' age and sex (State Veterinary Administration 2017).

Considering the above facts, a significant increase of the number of hunted animals and growing sales of wild boar meat in the retail network can be expected. This study aimed to obtain information on the chemical composition of wild boar meat in the Czech Republic and to determine whether different localities, age, and sex have an effect on the selected chemical properties of wild boar muscle tissue.

\section{Materials and Methods}

Samples were taken from wild boar (Sus scrofa) hunted at two selected localities: locality A and locality B. All wild boar were hunted during large-scale hunts. The samples were collected during the 2015-2016 and 2016-2017 hunting seasons. A total of 80 animals were analysed (58 from locality A - 32 females and 26 males; 22 from locality B - 12 females and 10 males). The selected localities were within a $150 \mathrm{~km}$ distance from one another, in different parts of the Czech Republic.

\section{Localities/production systems}

Locality A, representing an open production system, is located in the south-east of the Czech Republic and covers an area of 2,000 ha. The wild boar living in this locality also spent time on the surrounding agricultural land. The terrain of the hunting ground is hilly and forested. The Norway spruce (Picea abies) and European beech (Fagus sylvatica) dominate the forest vegetation. The hunted game here also includes the roe deer (Capreolus capreolus) and red deer (Cervus elaphus).

The free-living game sought food primarily on the surrounding agricultural land, though in the hunting season the animals were purposely fed a feed mix containing a majority of corn grain. The wild boar population density at the locality fluctuated during the course of the year. The average density ranged from 150 to $200 / 1,000$ ha. One third of the population of wild boar were killed by hunting during the course of the hunting season. Most of the wild boar were hunted by a group hunting method (driven shooting), and a smaller number shot during individual hunting (hunting from a hide).

Locality B, representing an enclosed production system, is located in the north-east of the Czech Republic and covers an area of 200 ha. The hunting ground is fenced (game preserve) with a flat and forested terrain. The 
Norway spruce (Picea abies), the common oak (Quercus robur) and the Scots pine (Pinus sylvestris) dominate the forest vegetation. The hunted game here also includes the roe deer (Capreolus capreolus) and the Sika deer (Cervus nippon). Their primary food source was a complete feed with corn grain as the primary constituent. The game also supplemented their diet with acorns from the oaks. The wild boar population density was intentionally managed and was increased by wild boar from other localities in addition to the natural growth. The average density was 1,200/1,000 ha. Most of the wild boar were hunted by the group hunting method (driven shooting). Wild boar were selected before planned hunts to avoid valuable individuals being hunted.

\section{Sampling}

A sample of muscle tissue from the medial part of the shoulder (musculus teres major) was taken from the left and right sides of each hunted wild boar in co-operation with the employees of the Faculty of Forestry and Wood Technology at Mendel University. These samples were placed in labelled bags immediately after they were taken. The following indices were recorded for each individual: sex, age and, weight. Age was determined by the tooth eruption and replacement pattern (Matschke 1967). The animals were divided into the groups of piglets ( $<1$ year) and yearlings (1-2 years). The mean age of the piglets was 8 months; the mean age of the yearlings was 21 months. The mean weight of the piglets was $33 \mathrm{~kg}$; the mean weight of the yearlings was $68 \mathrm{~kg}$.

All samples were transported as quickly as possible to the Department of Meat Hygiene and Technology at the University of Veterinary and Pharmaceutical Sciences Brno where they were cleaned, frozen (within $12 \mathrm{~h}$ after killing) and stored at $-18{ }^{\circ} \mathrm{C}$. The samples were moved to a refrigerator box the day before analysis where they were defrosted at $2{ }^{\circ} \mathrm{C}$ and subsequently comminuted in a grinder.

\section{Laboratory analysis}

Laboratory analysis focused on basic chemical properties: the contents of fat, crude protein, pure protein, collagen, dry matter and ash.

Content of crude protein: Crude (total) protein was analysed according to the Kjeldahl method on a Kjeltec 2300 (FOSS, Sweden) according to CSN ISO 937. A factor of 6.25 was used to calculate the crude protein content from the content of determined nitrogen.

Content of pure protein: After precipitation with a hot tannin solution, the Kjeldahl method was used on a Kjeltec 2300 (FOSS, Sweden) for determination of pure protein with the same factor of 6.25 for calculation.

Content of fat: The content of fat in the samples originating from wild boar was determined by the Soxhlet method on a Soxtec 2055 (FOSS, Sweden) with the reaction solvent petroleum ether.

Collagen: The content of collagen was calculated from the values of 4-hydroxyproline $($ factor $=8$ ), which was determined by the spectrophotometric method after its reaction with $p$-dimethylaminobenzaldehyde.

Dry matter content: The dry matter content was determined according to ČSN 576021 in a dryer at a temperature of $103 \pm 2{ }^{\circ} \mathrm{C}$ for $24 \mathrm{~h}$.

Ash: The content of ash was determined in a muffle furnace after mineralisation of samples at $550{ }^{\circ} \mathrm{C}$ according to ČSN ISO 936.

\section{Statistical analysis}

Wild boar carcasses were divided into two groups according to locality and then according to age (group 1 = 1-12 months, group 2=13-24 months) and sex. The results were statistically analysed in the programs Excel 2013 and Statistica v. 7.0, StatSoft CZ. For statistical comparison of the two localities, and the effects of sex and age, $t$-test for independent samples with a level of significance of 0.05 was used.

\section{Results}

The results obtained from two different localities show the effect of environment, sex and age on the selected chemical properties of wild boar meat (Table 1).

\section{Crude protein and pure protein}

A higher protein content was found at locality A. The protein content exceeded $20 \%$ in all age groups at this locality. The highest contents of crude protein and pure protein were determined in females in the category 13-24 months (21.26\% and $19.18 \%$, respectively). Statistical analysis confirmed the higher content of crude protein $(P<0.05)$ and pure protein $(P<0.05)$ in the samples from locality A. The content of protein at locality B was lower, ranging from 18.77 to $20.34 \%$. 
Table 1. Chemical composition of musculus teres major in wild boar from two localities in the Czech Republic (mean \pm S.D.).

\begin{tabular}{|c|c|c|c|c|c|c|c|}
\hline Group & Locality & Crude protein \% & Pure protein $\%$ & Collagen $\%$ & Fat $\%$ & Dry matter $\%$ & Ash \% \\
\hline \multicolumn{8}{|l|}{ Piglets } \\
\hline $\mathrm{n}=56$ & A & $20.50 \pm 1.06$ & $18.61 \pm 1.13$ & $0.81 \pm 0.29$ & $1.56 \pm 0.73^{\mathrm{a}}$ & $25.00 \pm 1.51$ & $1.01 \pm 0.14$ \\
\hline \multicolumn{8}{|l|}{ Piglets } \\
\hline $\mathrm{n}=24$ & B & $19.34 \pm 1.48$ & $17.49 \pm 1.68$ & $1.04 \pm 0.45$ & $2.31 \pm 0.94^{\mathrm{b}}$ & $26.31 \pm 2.49$ & $0.87 \pm 0.22$ \\
\hline \multicolumn{8}{|l|}{ Piglets F } \\
\hline $\mathrm{n}=24$ & A & $20.64 \pm 0.99$ & $18.60 \pm 0.74$ & $0.74 \pm 0.29$ & $1.42 \pm 0.58^{\mathrm{a}}$ & $24.62 \pm 0.91$ & $1.02 \pm 0.19$ \\
\hline \multicolumn{8}{|l|}{ Piglets F } \\
\hline$n=16$ & B & $19.63 \pm 1.73$ & $17.81 \pm 1.89$ & $1.21 \pm 0.45$ & $2.38 \pm 1.04^{b}$ & $26.48 \pm 2.41$ & $0.81 \pm 0.25$ \\
\hline \multicolumn{8}{|c|}{ Piglets M } \\
\hline $\mathrm{n}=32$ & A & $20.40 \pm 1.10$ & $18.62 \pm 1.35$ & $0.87 \pm 0.28$ & $1.67 \pm 0.73$ & $25.29 \pm 1.78$ & $1.00 \pm 0.08$ \\
\hline \multicolumn{8}{|c|}{ Piglets M } \\
\hline $\mathrm{n}=8$ & B & $18.77 \pm 0.31$ & $16.86 \pm 0.23$ & $0.69 \pm 0.09$ & $2.17 \pm 0.67$ & $25.96 \pm 2.6$ & $1.01 \pm 0.03$ \\
\hline \multicolumn{8}{|l|}{ Yearlings } \\
\hline$n=60$ & A & $20.97 \pm 1.00$ & $19.06 \pm 0.74$ & $0.90 \pm 0.65$ & $1.12 \pm 0.67$ & $25.80 \pm 0.89$ & $0.89 \pm 0.31$ \\
\hline \multicolumn{8}{|l|}{ Yearlings } \\
\hline $\mathrm{n}=20$ & B & $20.14 \pm 0.55$ & $18.46 \pm 0.50$ & $0.78 \pm 0.12$ & $1.59 \pm 0.53$ & $25.59 \pm 1.36$ & $0.89 \pm 0.25$ \\
\hline \multicolumn{8}{|c|}{ Yearlings F } \\
\hline $\mathrm{n}=40$ & A & $21.26 \pm 1.11$ & $19.18 \pm 0.83$ & $0.94 \pm 0.78$ & $1.29 \pm 0.66^{\mathrm{a}}$ & $26.19 \pm 0.68$ & $0.84 \pm 0.36$ \\
\hline \multicolumn{8}{|c|}{ Yearlings F } \\
\hline $\mathrm{n}=8$ & B & $20.34 \pm 0.69$ & $18.28 \pm 0.64$ & $0.88 \pm 0.13$ & $1.72 \pm 0.39^{b}$ & $26.43 \pm 1.39$ & $0.71 \pm 0.31$ \\
\hline \multicolumn{8}{|c|}{ Yearlings M } \\
\hline $\mathrm{n}=20$ & A & $20.49 \pm 0.49$ & $18.85 \pm 0.48$ & $0.83 \pm 0.32$ & $0.83 \pm 0.59$ & $25.15 \pm 0.81$ & $1.00 \pm 0.09$ \\
\hline \multicolumn{8}{|c|}{ Yearlings M } \\
\hline $\mathrm{n}=12$ & B & $20.01 \pm 0.37$ & $18.58 \pm 0.33$ & $0.71 \pm 0.04$ & $1.51 \pm 0.60$ & $25.03 \pm 1.00$ & $1.01 \pm 0.06$ \\
\hline \multicolumn{8}{|l|}{ Total } \\
\hline$n=116$ & A & $20.78 \pm 1.04^{\mathrm{a}}$ & $18.81 \pm 0.96^{\mathrm{a}}$ & $0.87 \pm 0.52$ & $1.30 \pm 0.73^{\mathrm{a}}$ & $25.41 \pm 1.30$ & $0.94 \pm 0.26$ \\
\hline \multicolumn{8}{|l|}{ Total } \\
\hline$n=44$ & B & $19.71 \pm 1.22^{\mathrm{b}}$ & $17.93 \pm 1.38^{b}$ & $0.92 \pm 0.36$ & $1.98 \pm 0.86^{\mathrm{b}}$ & $25.98 \pm 2.08$ & $0.88 \pm 0.24$ \\
\hline
\end{tabular}

S.D. - standard deviation; $\mathrm{n}$ - number of analysed samples; $\mathrm{F}$ - female; $\mathrm{M}$ - male; ${ }^{\mathrm{a}, \mathrm{b}}$ - significant differences $(P<0.05)$ between the two localities

Fat

The values obtained in the analysis of the fat content fell within the wide range of $0.83-2.38 \%$. A higher content of fat in muscles from the medial part of the shoulder was found in all samples from locality B. The highest fat content was found in the category wild piglets - females aged $1-12$ months $(2.83 \%)$. Statistical evaluation confirmed a significant difference $(P<0.05)$ between the studied localities in the fat content of the medial muscle of the shoulder. Comparison of the category 1-12 months in localities A and B showed that wild piglets from locality $\mathrm{B}$ had a significantly higher content of fat that those from locality A, and this was also confirmed by the results of statistical evaluation. A significant difference $(P<0.05)$ was found between wild piglets. When the analysed samples were divided by sex, a significant difference in the fat content was found at the studied localities between the groups of younger $(0-12$ months $)$ female wild boar $(P<0.05)$ and also between the groups of older (12-24 months) female wild boar. 


\section{Collagen}

The content of collagen in the analysed muscle samples fell within the range of $0.69-1.04 \%$. Statistical analysis did not demonstrate any effect of locality, sex or age on the collagen content in the muscle tissue of wild boar.

\section{Dry matter/moisture}

The values obtained for the dry matter content fell within the range of $24.62-26.43 \%$. The results showed a higher dry matter content in females, with the single exception of the category male wild piglets from locality A, though no significant difference was found during data evaluation by statistical analysis.

\section{Ash}

The ash content fell within the range of $0.81-1.02 \%$ in the age category $0-12$ months and within the range of $0.71-1.01 \%$ in the age category $12-24$ months. Statistical evaluation did not show any effect of age, sex or locality on the content of ash in the analysed samples.

\section{Discussion}

\section{Protein}

The results obtained from the two localities are in accordance with other studies conducted in Europe. Strazdina et al. (2011), for example, obtained a wide range of protein values (18.16-25.88\%) in $\mathrm{m}$. longissimus lumborum from 12 individual wild boars. This wide range may have been caused by different age categories and environments which were not specified in the study.

In accordance with our study, locality was also determined to have a significant effect on the protein content in a study conducted by Amici et al. (2015) which confirmed a significant difference $(P<0.05)$ between two of the three studied localities in the $\mathrm{m}$. longissimus lumborum of wild boar in the age category of yearlings. The quantity of protein determined in the research $(20.7-21.84 \%)$ corresponded to our results $(20.01-21.6 \%)$ in animals of the same age.

A similar result was obtained in a study conducted in Italy, in which a higher protein content was determined in samples (m. longissimus dorsi) from a field environment compared to samples from a forest hunting ground, though only in the group of studied wild boar aged 12-24 months. A significant effect of age on the protein content was also found $(P<0.01)$, with a higher protein content in older animals (Pedrazzoli et al. 2017), which is in accordance with the results of our study, although in our case the difference was not significant. A significant effect was also obtained in a study in Germany. During studies on the effect of age, sex and locality on the protein content in muscle tissue (m. longissimus), a significant effect $(P<0.05)$ on the protein content was found only in the group of wild boar (males) aged more than 12 months at two different localities. No significant effect was observed in females in the same age category or in wild boar (males and females) younger than 12 months (Dannenberger et al. 2013).

On the other hand, a Hungarian study found no differences in the protein content in the muscle tissue ( $\mathrm{m}$. serratus anterior) between localities in which wild boar were intensively fed a feed mix and a locality in which wild boar were dependent exclusively on natural sources. The age and sex of the wild boar were not specified in the study which may have influenced the differing results (Skobrák et al. 2011).

Also, a Romanian study based on comparison of four different muscle groups ( $\mathrm{m}$. longissimus lumborum, $\mathrm{m}$. longissimus thoracis, $\mathrm{m}$. intercostalis and $\mathrm{m}$. semitendinosus) did not find any significant difference between sexes in the analysed samples of 10 wild boar. This result may have been caused by the small number of representative samples and 
the non-determination of the weight or age of the analysed animals (Lazăr et al. 2014). Similarly to the above mentioned studies, the difference between sexes was not significant in our study, although females generally showed a higher content of crude protein in meat than males.

Fat

The content of fat is a highly variable indicator. It is influenced by many factors and its value falls within the range of around 1-4\% in wild game meat (Skobrák et al. 2011).

We proved a higher fat content in animals from the fenced hunting ground, which could be related to the different habitat (flat ground, limited size of the enclosure) and feeding conditions (acorns, a stable source of feed - corn feed mix available during the whole year). Similarly, the study by Skobrák et al. (2011) conducted in Hungary determined a significantly lower fat content in wild boar that came from a locality where feed mixes were not supplied (4.27\%) as compared to a semi-intensively and intensively fed wild boar $(14.12 \%$ and $6.74 \%)$. A higher intramuscular fat content was found in wild boar hunted in arable forest areas, where some highly caloric cultivated plants were available, compared to those hunted in a marshy area (Źochowska-Kujawska et al. 2010). On the other hand, no significant effect on the content of fat in the muscle tissue of wild boar aged $17.4 \pm 4.51$ months was found between the studied localities in an Italian study in which samples of $\mathrm{m}$. longissimus lumborum from three different hunting grounds were analysed (Amici et al. 2015).

This finding was confirmed by a German study which assessed the effect of age, sex and different localities on the content of fat in the muscle ( $\mathrm{m}$. longissimus). A wide range of results for the fat content in the muscle of wild boar was obtained, for which reason the result was non-significant. The obtained variable results were put down to the non-standard composition of the diet of free-living animals (Dannenberger et al. 2013).

The effect of sex was also studied. Although the difference in fat content between females and males in general was not significant in our study, the differences between localities were clearly more pronounced in females than in males (Table 1). No significant effect of sex on the fat content was found in the category of yearlings (13-24 months) by Skobrák et al. (2011).

Different results were recorded in a study in Italy which compared the category yearlings (12-24 months) with the category adult wild boar ( $>24$ months) from two localities forest and farmland. A significant effect of the age of the animals $(P<0.001)$ on the content of intramuscular fat was determined, though in contrast to our own results the authors determined a higher fat content in the group of animals over 24 months of age (Pedrazzoli et al. 2017).

\section{Collagen}

Strazdina et al. (2014) found much higher values for the collagen content in wild boar $(1.45 \%)$. Their research did not, however, state the weight or age of the analysed animals, and their results may have been caused by the higher age and weight of the wild boar in question.

The effect of sex on the collagen content in the Romanian study was not significant, although females displayed higher values as in our study. This fact was put down to the analysed samples which in the case of females came from younger animals (Lazăr et al. 2014).

\section{Dry matter}

No influence of the three factors on the dry matter content was proved. A similar result was obtained by Dannenberger et al. (2013) who did not demonstrate any significant 
effect of locality, sex or age in the same groups ( $0-12$ months and more than 12 months) on the water content in the muscle tissue of wild boar (m. longissimus). The Romanian study monitored the effect of sex and muscle parts (m. longissimus lumborum, m. longissimus thoracis, $\mathrm{m}$. intercostalis and $\mathrm{m}$. semitendinosus) on the water content. Assessment of the effect of sex demonstrated a higher water content in the female sex, i.e. a higher content of dry matter in males, though this was non-significant. This result was explained by younger animals of the female sex (Lazăr et al. 2014).

An Italian study, in contrast, which studied the effect of locality and sex on selected chemical properties of the muscle tissue (m. longissimus dorsi) of wild boar, determined a significantly higher water content $(P<0.001)$ in the muscle tissue of animals aged 12-24 months (yearlings) than in animals older than 24 months (Pedrazzoli et al. 2017).

Another Italian research also studied the effect of locality on the $\mathrm{m}$. longissimus lumborum in wild boar aged $17.4 \pm 4.51$ months hunted at three selected localities. Statistical analysis confirmed an effect of locality $(P<0.05)$ on the content of dry matter, with one locality differing significantly from the others (Amici et al. 2015).

\section{Ash}

In our study, no influence of the three factors on the ash content was proved. This finding is backed up by the Italian study by Amici et al. (2015) which compared the effect of locality and age on the content of ash in the muscle tissue of wild boar (m. longissimus dorsi). Wild boar at an age of $17.4 \pm 4.51$ months were hunted at three different localities in central Italy. The study did not demonstrate a significant effect of locality on the content of ash, though the values obtained were higher (1.25-1.28) than the results we obtained for the same age category of wild boar.

Based on the results, it can be said that the production system in the localities and, to a lesser extent, the sex and age of animals had a significant effect on selected chemical properties of the meat of wild boar. The main differences were found in the contents of protein and fat, which can be explained mainly by differences in the feed variety, amount and availability (corn grain, acorns). It would be appropriate to obtain a larger number of samples from the same age categories from additional localities for further research and to expand the studied properties to include microelements and the composition of fatty acids.

\section{Acknowledgements}

This research was carried out under the project CEITEC 2020 (LQ1601) with financial support from the Ministry of Education, Youth and Sports of the Czech Republic under the National Sustainability Programme II. The study was also financially supported by IGA VFU Brno (Grant number 225/2016/FVHE).

\section{References}

Act no. 449/2001 Coll., on gamekeeping. Available at: http://www.zmenyzakonu.cz/zakon.aspx?id = 34519. Last modified January 1, 2018. Accessed January 18, 2018

Act no. 166/1999 Coll., on veterinary care and on a change of some related laws (veterinary act). Available at: http://www.zmenyzakonu.cz/zakon.aspx?id = 34531. Last modified January 1, 2018. Accessed January 18 , 2018

Amici A, Cifuni GF, Contò M, Esposito L, Failla S 2015: Hunting area affects chemical and physical characteristics and fatty acid composition of wild boar (Sus scrofa) meat. Rend Lincei-Sci Fis 26: 527-534

Czech Statistical office. Available at: https:/www.czso.cz/documents/10180/36741233/1000051603.pdf/ fed976be-1ae5-4502-a4e0-8c28bb4132e3?version =1.0. Last modified August 15, 2018. Accessed December 18,2017

ČSN 57 6021: 1999 (ISO 1442: 1997). Examination of meat products and canned sterilized food - The determination of water content (Reference method). Czech Standards Institute, Prague, $8 \mathrm{p}$.

ČSN ISO 937: 2002. Meat and meat products - Determination of nitrogen content (Reference method). Czech Standards Institute, Prague, 8 p. 
ČSN ISO 936: 2016. Meat and meat products - Determination of total ash. Czech Office for Standards, Metrology and Testing, Prague, $12 \mathrm{p}$.

Dannenberger D, Nuernberg G, Nuernberg K, Hagemann E 2013: The effects of gender, age and region on macro- and micronutrient contents and fatty acid profiles in the muscles of roe deer and wild boar in Mecklenburg-Western Pomerania (Germany). Meat Sci 94: 39-46

Decree no. 245/2002 Coll., on the hunting season for individual species of animals and on detailed conditions for hunting. Available at: http://www.zmenyzakonu.cz/zakon.aspx?id = 31637. Last modified January 1, 2016. Accessed January 19, 2018

Lazăr M, Lazăr R, Diaconu NG, Boişteanu, PC 2014: Research regarding the characterization of the nutritional profile of wild boar (Sus scrofa ferus). Bulletin UASVM Animal Science and Biotechnologies 71: 291-292

Matschke GH 1967: Ageing European wild hogs by dentition. J Wildl Manage 31: 109-113

Pedrazzoli M, Bosco AD, Castellini C, Ranucci D, Mattioli S, Pauselli M, Roscini V 2017: Effect of age and feeding area on meat quality of wild boars. Ital J Anim Sci 16: 353-362

Sales J, Kotrba R 2013: Meat from wild boar (Sus scrofa L.): A review. Meat Sci 94: 187-201

Skobrák EB, Bodnár K, Jónás EM, Gundel J, Jávor A 2011: The comparison analysis of the main chemical composition parameters of wild boar meat and pork. J Anim Sci Biotechnol 44: 105-112

State Veterinary Administration. Regulation of the State Veterinary Administration - exceptional veterinary measures to prevent the spreading of a dangerous disease - African swine fever on the territory of the Czech Republic. Available at: http://www.svscr.cz/wp-content/files/zvirata/Narizeni_platna_v_cele_CR_20180302. pdf. Last modified October 5, 2017. Accessed November 13, 2017

Strazdina V, Jemeljanovs A, Sterna V, Vjazevica V 2011: Evaluation of protein composition of game meat in Latvian farms and wildlife. Agron Res 9: 469-472

Strazdina V, Jemeljanovs A, Sterna V, Ikauniece D 2014: Nutritional characteristics of wild boar meat hunted in Latvia. In: 9th Baltic Conference on Food Science and Technology 'Food for Consumer Well-Being' FOODBALT 2014 Conference Proceedings. LLU, Jeglava: 32-36

Żochowska-Kujawska J, Lachowicz K, Sobczak M, Bienkiewicz G 2010: Utility for production of massaged products of selected wild boar muscles originating from wetlands and an arable area. Meat Sci 85: 461-466 